\title{
Effect of housing systems on the growth performance of crossbred goats *
}

\author{
CHAMPAK BHAKAT'1 and P K NAGPAUL 2 \\ National Dairy Research Institute, Karnal, Haryana, 132001 India
}

Received: 31 July 2003; Accepted: 16 September 2004

\begin{abstract}
Growth rate, leed conversion efficiency, DMI and CPI of 30 crossbred female kids (up to the 16-month-old) were studied. Kids (30) were divided into 3 groups of 10 each. Kids under 3 treatments were housed as: group 1 - concrete floor with concrete roof; group 2: kuccha floor with thatched roof, group 3: raised-slotted floor with thatched roof. Body weight and DM intuke of kids were recorded at fortnightly intervals. Housing and age of kids and seasons significantly affected the total DMI and CPI. The DMI and CPI through concentrate and green fodder gradually increased with the advancement of age of kids. The highest DMI and CPI through concentrate and fodder were in group 3 followed by group 2 and the lowest was in group 1. The housing and age of kids and season significantly affected the DMI per kg body weight gain and the CPI/kg body weight gain with the best conversion of DMI and CPI into growth (body weight gain) in the third group. The housing treatments and seasons had significant effect on body weight of kid at each month of age except at 4 month of age of kid. The cost $/ \mathrm{kg}$ body weight was lowest in third group and highest in first group. The fixed and variable cost analysis reveal that thatch roofed kuccha shelter was quiet economical than concrete floor with concrete roof shelter. The study concludes that the raised-slotted floor with thatched roof shed is the best suited for crossbred female kids in terms of growth, feed conversion efficiency and economics. The kukcha floor with thatched roof shed has good practical economic significance and also better for crossbred female kids as compared to the concrete floor with concrete roof shed.
\end{abstract}

Kcy words: Feed intake, Feed conversion efficiency, Goats, Growth, Housing system

Some of the special qualities of goats, like fastidious feeding habits, browsing nature, survivability to poor quality roughages and large variety of feeds, and fallen leaves that other animals will frown at, high fecundity and low management input, make this species very unique. The main problem of kid rearing in the post-weaning period is related to poor growth rate because of poor management. The main purpose of goat housing is to moderate the range of microenvironment to which the animals are exposed and optimise their growth and better survivability by protecting them from extreme climates and satisfactory working conditions for animal's caretakers. Jagadale (1981) reported that total DM consumption $/ 100 \mathrm{~kg}$ body weight was more in goats kept free during day and night time having open access to covered and open area. Rokde and Tomer (2001). concluded that housing had highly significant effect on body composition of crossbred calves. Keeping in view of above important points, the present study is conducted with a major objective to study the effect of housing on growth

* Part of Ph.D. Thesis submitted to NDRI (Deemed University), Karnal, Haryana, India.

Present address: 'Scientist (SS) at NRC on Camel, Jorbeer, PB 07, Bikaner, Rajasthan 334001.

2Principal Scientist. performance of crossbred kids.

\section{MATERIALS AND METHODS}

Female crossbred (Alpine $\times$ Beetal) kids (30), around 4month-old were allotted randomly into 3 comparable groups (housing), so that the average body weight of all the groups was more or less similar. The 3 treatment groups comprised 3 types of housing which has $10 \mathrm{kids}$ each. The fundamental construction of each shed was almost same having a covered and open area. The features and dimension of 3 groups are given below.

\begin{tabular}{|c|c|c|c|c|c|}
\hline \multicolumn{2}{|c|}{ Groups Floor } & \multirow[t]{2}{*}{ Roof } & \multicolumn{2}{|c|}{ Height of } & \multirow[b]{2}{*}{$\begin{array}{l}\text { Width } \\
\text { of gate }\end{array}$} \\
\hline & & & Roof & $\begin{array}{c}\text { Boundary } \\
\text { wall }\end{array}$ & \\
\hline 1 & Concrete & Concrete & 9.5 & 5,00 & 2.5 \\
\hline 2 & Kuccha & Thatched & $\begin{array}{l}9.5 \text { (front) } \\
5.5 \text { (back) }\end{array}$ & 5.00 & 2.5 \\
\hline 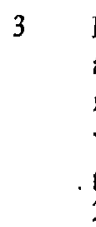 & $\begin{array}{l}\text { Raised slotted } \\
\text { at height } \\
\text { made up } \\
\text { wooden planks, } \\
\text { gap between } \\
2 \text { slots }-2.5 \mathrm{~cm}\end{array}$ & Thatched & $\begin{array}{l}9.5 \text { (front) } \\
5.5 \text { (back) }\end{array}$ & 5.00 & 2.5 \\
\hline
\end{tabular}


Size of feeding manger provided in all 3 sheds was $11 \mathrm{ft}$ (length) $\times 1.5 \mathrm{ft}$ (breadth) $\times 2.5 \mathrm{ft}$ (height). Space requirement was given according to ISI standard (1978), which was 5.44 sqft (covered area) and 10.89 sqft (open area) for each kid (4-16 months aged). All kids were fed similar kind of fodder and concentrate as per feeding schedule followed at NDRI farm. General management was similar to the one which is being practiced there.

Body weight of the kids was recorded first before sinifting the kids to the respective treatments and, thereafter all the experimental animals were weighed at fortnightly intervals. The average weight of 2 consecutive days was taken to represent fortnightly body weight. The weighing was always. done in the morning before offering feed or water. Body weight formed the basis of determining the growth rate of the animals. The samples of fodder and concentrate mixtures were collected and analysed for DM and CP at fortnightly intervals. Dry matter intake of the anitnals was also recorded at fortnightly interval by making measurements of feed offered and residue left. The DM of sample was determined by drying the sample in a hot air oven at $99 \pm 1{ }^{\circ} \mathrm{C}$ for overnight. Feed conversion efficiency was determined according to standard methods. Microclimatic component like maximum and minimum temperature, dry bulb and wet bulb temperature, relative humidity (morning - evening) were recorded under concrete roof and thatched roof shed and from macro-environment daily for 1 year. Temperature humidity index (morning - evening) was calculated for concrete roof and thatched roof shed. The 2-way analysis of variance procedures (Snedecor and Cochran 1989) were applied for the analysis of experimental data.

\section{RESULTS AND DISCUSSION}

\section{Dry matler intake (DMI)}

The DM intake through concentrate and fodder gradually increased with the advancement of experiment. The highest DM intake through concentrate was in group $3(0.302 \pm 0.014$ $\mathrm{kg})$ followed by group $2(0.297 \pm 0.015 \mathrm{~kg})$ and the lowest in group $1(0.287 \pm 0.016 \mathrm{~kg})$. The DM content of concentrate mixture fed to all groups was about $90.0 \%$. Despite the similar DM content and quantity of feed offered, the intake in 3 groups was different, which might be due to the difference in the types of housing provided to 3 groups of kids. As the experiment advanced, the DMl through fodder gradually increased. The highest DMI through fodder was in group' 3 $(0.452 \pm 0.035 \mathrm{~kg})$, followed by group $2(0.450 \pm 0.035 \mathrm{~kg})$ and the lowest in group $1(0,427 \pm 0.025 \mathrm{~kg})$. These results are in close agreement with Yadav and Singh (1995) and Angami et al. (1992).

\section{Total dry matter intake}

However, the second group had only kuccha floor, which caused dampness during rainy seasons and also caused cold stress during winter. The goat by habit, prefer a dry and clean place. This dry and clean place or floor was provided to the third group. So, the animals in third group felt quite comfortable in the type of housing provided to them and showed the ability for the maximum consumption of dry matter. In group 1, the total DMI was the lowest, which might be due to environmental stress, as this pirticular was provided with concrete floor with concrete roof housing. Our results with regard to total DM intake also corroborated with the reports of Nand Kishore et al. (1990).

\section{Crude protein intake (CPI)}

The highest CPI through fodder was in group 3 $(0.068 \pm 0.005 \mathrm{~kg})$ followed by group $2(0.067 \pm 0.005 \mathrm{~kg})$ and the lowest in group $1(0.065 \pm 0.004 \mathrm{~kg})$. Similar trend was in CPI through concentrate.

\section{Total CP intake}

The highest total CPI was in group $3(0.131+0.007 \mathrm{~kg})$ followed by group $2(0.130 \pm 0.007 \mathrm{~kg})$ and the lowest in group $1(0.125 \pm 0.006 \mathrm{~kg})$. With the advancement of age of the kid, not only the total DMI increased, but total CPI was also increased. Our results with respect to C.P intake were in agreement with Yadav and Singh (1995). DMI and CPI significantly $(P<0.01)$ affected by housing systems.

\section{Body weight gain}

The mean values of body weight gain and feed conversion efticiency in different housing and season is given in Table 1. During the $4-5$ month age, it was $0.05 \mathrm{~kg}, 0.07 \mathrm{~kg}$ and $0.09 \mathrm{~kg}$ in the groups 1,2 and 3 , respectively, and during the 16 month age, it was $0.05 \mathrm{~kg}, 0.06 \mathrm{~kg}$ and $0.09 \mathrm{~kg}$ in the groups 1,2 and 3 respectively. Body weight gain was significantly $(P<0.01)$ affected by group (housing) and period (age of kid), The significant variation in body weight gain was presumably because of the variation in total DMI and CPI in different types of housing. The lower growth rate (body weight gain) was found by Jaikishan et al. (1982) and Krishma and Prasad (1985). However, the results are in close agreement with the reports of Mishra and Ghel (1990). During extreme summer and winter body weight gain adversely affected in groupl, followed by groups 2 and 3. Season had significant $(\mathrm{P}<0.01)$ effect on body weight gain of kids under different housing systems.

\section{Feed conversion efficiency}

$D M I / k g$ body weight gain: The mean values were 9.64, 6.67 and $5.05 \mathrm{~kg}$ in groups 1,2 and 3 , respectively, during the $4-5$ month age and $18.20,15.69$ and $11.54 \mathrm{~kg}$, during the 16 month age in the groups 1,2 and 3 respectively. The DMI per $\mathrm{kg}$ body weight gain was significantly $(P<0.01)$ affected by group (housing) and also by period (age of kid), and season with group 3 having the best feed conversion efticiency.

CPI/kg body weight gain: It was $1.86,1.23$ and $0.94 \mathrm{~kg}$ during 4-5 month age and $3.10,2.69$ and $1.95 \mathrm{~kg}$ during the 16 month age in the groups 1,2 and 3 respectively. The CPI 
Table 1. The mean values of body weight gain and feed conversion efficiency in different housing and season

\begin{tabular}{|c|c|c|c|c|c|c|c|c|c|c|c|c|c|}
\hline \multirow[t]{2}{*}{ Parameters } & \multirow[b]{2}{*}{ Age of } & \multicolumn{3}{|c|}{$\begin{array}{c}\text { Summer } \\
\text { (April, May, June) }\end{array}$} & \multicolumn{2}{|c|}{$\begin{array}{c}\text { Rainy } \\
\text { (Silly, Aug) }\end{array}$} & \multicolumn{2}{|c|}{$\begin{array}{l}\text { Autumn } \\
\text { (Sep, Oct) }\end{array}$} & \multicolumn{3}{|c|}{$\begin{array}{c}\text { Winter } \\
\text { (Nov, Dec, Jan) }\end{array}$} & \multicolumn{2}{|c|}{$\begin{array}{l}\text { Spring } \\
\text { (Feb, Mas) }\end{array}$} \\
\hline & & $4-5$ & 6 & 7 & 8 & 9 & 10 & 11 & 12 & 13 & 14 & 15 & 16 \\
\hline \multirow{3}{*}{$\begin{array}{l}\text { Body weight } \\
\text { gain (kg/day) }\end{array}$} & Gr. I & $0.05^{\mathrm{a}}$ & $0.05^{\mathrm{b}}$ & $0.05^{\mathrm{c}}$ & $0.05^{d}$ & $0.05^{\mathrm{c}}$ & $0.05^{r}$ & $0.05^{5}$ & $0.05^{\mathrm{h}}$ & $0.05^{\prime}$ & 0.05 & $0.05^{b}$ & $0.15^{1}$ \\
\hline & $\mathrm{Gr}, 2$ & $0.07^{\mathrm{a}}$ & $0.07^{\prime \prime \prime}$ & $0.07^{n}$ & $0.07^{n}$ & $0.07 \mathrm{p}$ & $0.07^{\mathrm{q}}$ & $0.07^{r}$ & $0.07^{\mathrm{s}}$ & $0.06^{\prime}$ & $0.06^{\prime \prime}$ & $0.06^{\circ}$ & $0.06^{\prime \prime}$ \\
\hline & Gr.3 & $0.09^{a}$ & $0.10^{\mathrm{n}}$ & $0.10^{\prime}$ & $0.10^{\prime}$ & $0.10^{b}$ & $0.10^{\circ \mathrm{c}}$ & $0.10^{\mathrm{xe}}$ & $0.10^{\mathrm{d}}$ & $0.09^{\mathrm{si}}$ & $0.09^{\mathrm{Nr}}$ & $0.09 \cong$ & $0.06^{\text {th }}$ \\
\hline $\begin{array}{l}\text { Feed conversion } \\
\text { efficiency }\end{array}$ & n G.l & $9.64^{n}$ & $10.92^{\mathrm{b}}$ & $10.57^{\mathrm{c}}$ & $10.5 \mathrm{I}^{\mathrm{d}}$ & $12.00^{\circ}$ & $13.91^{\mathrm{r}}$ & $13.42^{b}$ & $13.33^{\prime \prime}$ & $15,42^{i}$ & $16.48^{\prime}$ & $17.10^{\mathrm{h}}$ & $18.20^{\prime}$ \\
\hline \multirow{5}{*}{$\begin{array}{l}\text { I DMI/kg body } \\
\text { weight gain } \\
2 \mathrm{CPI} / \mathrm{kg} \text { body } \\
\text { weight gain }\end{array}$} & G.2 & $6.67^{a}$ & $7.82^{\mathrm{nt}}$ & $7.61^{\mathrm{n}}$ & $7.67^{\circ}$ & $8.94^{\mathrm{n}}$ & $10.12^{q}$ & $9.84^{r}$ & $9.75^{s}$ & $12.34^{\prime}$ & $13.43^{\mathrm{u}}$ & $15.35^{\prime}$ & $15.69^{\prime \prime}$ \\
\hline & Gr.3 & $5.05^{\prime \prime}$ & $5.88^{x}$ & $5.86^{y}$ & $6.09^{\gamma}$ & $6.82^{7 n}$ & $7.47^{\circ}$ & $7.20^{\wedge}$ & $7.21^{\prime d}$ & $9.01^{\prime \prime}$ & $9.52^{\text {z1' }}$ & $11.14^{\prime \prime \prime}$ & $11.5+1$ \\
\hline & Gr. 1 & $1.86^{\mathrm{a}}$ & $2.08^{b}$ & $2.02^{\mathrm{c}}$ & $2.00^{\mathrm{d}}$ & $2.32^{\mathrm{e}}$ & $2.61^{\mathrm{r}}$ & $2.09^{g}$ & $2.13^{\mathrm{h}}$ & $2.54^{\prime}$ & $2.67^{\mathrm{J}}$ & $2.86^{h}$ & $3.10^{1}$ \\
\hline & Gr.2 & $1.23^{a}$ & $1.49^{\mathrm{m}}$ & $1.45^{n}$ & $1.45^{\circ}$ & $1.70^{\mathrm{p}}$ & $1.89^{\circ}$ & $1.55^{\mathrm{r}}$ & $1.57^{5}$ & $2.03^{\prime}$ & $2.13^{\circ}$ & $2.52^{\prime}$ & $2.69^{\mathrm{n}}$ \\
\hline & Gr.3 & $0.94^{n}$ & $1.11^{x}$ & $1.08 \mathrm{v}$ & $1.12^{\prime \prime}$ & $1,30^{\mathrm{sa}}$ & $1.40^{\mathrm{yb}}$ & $1.14^{\mathrm{cc}}$ & $1.15^{\mathrm{yd}}$ & $1.477^{\circ}$ & $1.54: r$ & $1.83^{18}$ & $1.95^{\mathrm{rh}}$ \\
\hline
\end{tabular}

Similar superscripts do not differ significantly $(P<0.01)$ from each other.

per $k g$ body weight gain was significantly $(\mathrm{P}<0.01)$ affected by housing, age of kid and season, with the best conversion of $\mathrm{CP}$ intake into growth (body weight gain) in third group. The present values are in close agreement with Angami et al. (1992).

Total DMI ( $\mathrm{kg}) /$ metabolic body size/day/kid: Total intake per day per $\mathrm{kg}$ metabolic body size $(\mathrm{kg})$ is presented in Table 2. During the first month, it was $0.066,0.066$ and $0.064 \mathrm{~kg}$ in groups 1, 2 and 3 respectively. The values were almost same during the first month. During 12 months of trial the values were $0.070,0.068$ and $0.059 \mathrm{~kg}$ for groups 1,2 and 3 respectively. The overall average were $0.070 \pm 0.001$ (group 1), $0.065 \pm 0.001$ (group 2) and $0.058 \pm 0.002$ (group 3 ).

The kids in the third group converted the feed more most efficiently into body mass. The second group was more efficient in converting the feed than the first group. which might be due to open type of house with thatched roof where the kids felt comfortable. Moreover, kuccha floor provided the scope of easy exercise than on concrete floor. In first group, kids were in stress condition throughout the experiment and remained idle with less exercise. So they did not efficiently convert the feed into body mass. The environmental stress becomes more severe during summer and winter, which adversely affected performance. But stress reduced in second group and least in third group for which kids showed better performance. Season, housing treatment, age significantly $(\mathrm{P}<0.01)$ affected performance of kids. The present values on DMI $(\mathrm{kg}) / \mathrm{W}^{075}$ is in close

Table 2. Total intake per day per kg metabolic body size (kg)

\begin{tabular}{|c|c|c|c|c|c|c|c|c|c|c|c|c|c|}
\hline \multirow{2}{*}{$\begin{array}{l}\text { Season' } \\
\text { Montlss } \\
\text { of trial }\end{array}$} & \multicolumn{3}{|c|}{ Summer } & \multicolumn{2}{|c|}{ Rainy } & \multicolumn{2}{|c|}{ Autumn } & \multicolumn{3}{|c|}{ Winter } & \multicolumn{2}{|c|}{ Spring } & \multirow[b]{2}{*}{$\begin{array}{l}\text { Overall } \\
\text { average }\end{array}$} \\
\hline & 1 & 2 & 3 & 4 & 5 & 6 & 7 & 8 & 9 & 10 & 11 & 12 & \\
\hline I st & 066 & 0 & $68^{* *}$ & $0.064^{* *}$ & $0.072^{* *}$ & $69 * *$ & $0.065^{* *}$ & $0.0 \mathrm{C}$ & ** & 0.0 & $0.070^{* *}$ & & 001 \\
\hline 2nd group & 0.066 & $0.07 I^{* * *}$ & $0.064 * *$ & $0.060^{* *}$ & $0.065^{* *}$ & $0.069 * *$ & $0.063 * *$ & $0.058 * *$ & $0.060^{* *}$ & $0.063^{* *}$ & $0.069^{* *}$ & $0.068^{* *}$ & $0.065 \pm 0.001$ \\
\hline 3rd group & 0.064 & $0.067 * *$ & $0.061^{* *}$ & $0.058^{* *}$ & $0.060 * *$ & $0.061^{* *}$ & $0.054 * *$ & $0.051^{* *}$ & $0.053^{* *}$ & $0.053^{* *}$ & $0.059^{* *}$ & $0.059 * *$ & $0.058 \pm 0.002$ \\
\hline
\end{tabular}

**Significant at $(\mathrm{P}<0.01)$

efficiently than second group and second group converted more efficiently than first group. The level of feed consumption and its efficiency of utilization is related to growth in growing kids. In third group, kids were provided raised slotted floor in covered area of shed. The kids remained dry and clean and in comfortable position than in second or first group. Moreover, the raised floor provided ample scope to kids to do the exercise all over the day and night. This might have resulted in increased digestive efficiency of kids and thus helped them to convert the feed agreemenl with Angami et al. (1992).

\section{Growth performance}

At 4 months of age, average body weight $(\mathrm{kg})$ of the kids was $12.79 \pm 0.26,12.75 \pm 0.25,12.77 \pm 0.25 \mathrm{~kg}$ in the groups 1 , 2 and 3 respectively (Table 3 ). Effect of housing on body weight at 4 months of age was nonsignificant. The animals took time (1 month) to adopt themself in their respective sheds, and the different housing system did not make significant changes in average body weights. Effect of 
Table 3. Body weight $(\mathrm{kg})$ for 3 lreatment groups in different seasons

\begin{tabular}{|c|c|c|c|c|c|c|c|c|c|c|c|c|c|c|}
\hline \multirow{2}{*}{$\begin{array}{l}\text { Treatment } \\
\text { age } \\
\text { (month) }\end{array}$} & \multirow{2}{*}{$\underset{\rightarrow}{N}$} & \multicolumn{4}{|c|}{ Summer } & \multicolumn{2}{|c|}{ Rainy } & \multicolumn{2}{|c|}{ Autumn } & \multicolumn{3}{|c|}{ Winter } & \multicolumn{2}{|c|}{ Spring } \\
\hline & & 4 & 5 & 6 & 7 & 8 & 9 & 10 & II & 12 & 13 & 14 & 15 & 16 \\
\hline \multirow[t]{2}{*}{ Gr. 1} & 10 & $12.79^{\mathrm{a}}$ & $14.20^{\mathrm{b}}$ & $15.68^{c}$ & $17.19^{4}$ & $18.72^{\mathrm{c}}$ & $20.32^{r}$ & $21.87^{\circ}$ & $23.40^{\mathrm{h}}$ & $24.87^{i}$ & $26.31^{\mathrm{j}}$ & $27.76^{\mathrm{h}}$ & $29.15^{1}$ & $30.48^{\prime \prime \prime}$ \\
\hline & & \pm 0.26 & \pm 0.25 & \pm 0.25 & \pm 0.25 & \pm 0.24 & \pm 0.24 & \pm 0.26 & \pm 0.25 & \pm 0.26 & \pm 0.28 & \pm 0.39 & \pm 0.56 & \pm 0.76 \\
\hline \multirow[t]{2}{*}{ Gr.2 } & 10 & $12.75^{4}$ & $14.85^{\prime \prime}$ & $17.00^{\circ}$ & $19.19 \mathrm{r}$ & $21.35^{7}$ & $23.53^{r}$ & $25.79^{\circ}$ & $27.70^{1}$ & $29.83 \mid$ & $31.65^{v}$ & $33.47^{\prime \prime}$ & $35.29^{\prime}$ & $37.11^{\mathrm{s}}$ \\
\hline & & \pm 0.25 & \pm 0.27 & \pm 0.25 & \pm 0.22 & \pm 0.21 & \pm 0.22 & 0.17 & \pm 0.30 & \pm 0.31 & \pm 0.30 & \pm 0.31 & \pm 0.30 & $\pm 0.3 !$ \\
\hline \multirow[t]{2}{*}{ Gr.3 } & 10 & $12.77^{3}$ & $15.55^{\prime}$ & $18.41^{n}$ & $21.29^{\mathrm{h}}$ & $24.19^{x}$ & $27.12^{7 d}$ & $30.06^{\text {is }}$ & $32.96^{4}$ & $35.86^{\mathrm{s}}$ & 38.38 & $40.90^{\prime \prime}$ & $43.42^{\prime}$ & $45.94^{\prime k}$ \\
\hline & & \pm 0.25 & \pm 0.25 & \pm 0.25 & \pm 0.24 & \pm 0.25 & \pm 0.24 & \pm 0.25 & \pm 0.24 & \pm 0.24 & \pm 0.25 & \pm 0.23 & \pm .24 & \pm 0.25 \\
\hline
\end{tabular}

Similar superscripts do not differ significantly $(P<0.01)$ from each other.

replication on body weight was found nonsignificant. Housing treatment significantly $(P<0.01)$ affected growth of kids of 5 month age onwards. From last 12 months observation, it was revealed that the difference between 3 groups increased constantly. This is because the kid could adapt well in the 2 newly designed experimental sheds which was reflected through their performance according to their comfortability in respective sheds. The highest body weight was observed in third group which might be due to the fact that the kids were in the most comfortable place (raisedslotted floor with thatched roof shelter) and suffered minimum environmental stress. This also lead to maximum consumption of DM and CP over the whole of the experimental period. It was followed by second group (body weight). The kids belonging to this group were also placed comfortably under the thatched roof, but felt some discomfort due to kuccha floor, which caused dampness specially during
$32.21 \pm 0.49$ but it was lowest under thatched roof shelter which varied from $12.06 \pm 0.51$ to $30.84 \pm 0.50 \mathrm{in}$ throughout a year. The present study was in agreement with the findings of Singh et al. (1989). In concrete shed THI was higher, and it was lower in thatched shed during summer and rainy seasons. Thus, the results indicated that under C.R shed kids were in least comfortable position and it was very stressful during the periods. The present result was supported by findings of Ghosh and Pan (1994).

The total variable cost for maintenance (feeding, health cover, labour etc) of kids were somewhat more in group 3 followed by groups 2 and 1 (Table 4). This is mainly due to higher feed consumption by kids belong to group 3. Body weight gain/kid in 12 months was highest in group $3(33.17$ $\mathrm{kg}$ ) and lowest in group $1(17.69 \mathrm{~kg})$. On contrary cost $/ \mathrm{kg}$ body weight was lowest in group 3 (Rs 33.96 ) and highest in group 1 (Rs 60.09). Maintenance cost (cleaning, labour ctc)

Table 4. Economic analysis of three types of housing and growth performance of kids during experimental period

\begin{tabular}{|c|c|c|c|c|c|c|c|}
\hline \multirow[b]{3}{*}{ Housing } & \multicolumn{6}{|c|}{ Variable cost } & \multirow{3}{*}{$\begin{array}{l}\text { Fixed cos } \\
\text { Total cost } \\
\text { (Rs) }\end{array}$} \\
\hline & \multicolumn{3}{|c|}{ Expenditure for maintenance of kids } & \multicolumn{3}{|c|}{ Expenditure for maintenance of housing } & \\
\hline & $\begin{array}{c}\text { Total cost } / \text { kid } \\
(R s)\end{array}$ & $\begin{array}{l}\text { Body weight gain } / \mathrm{kid} \text { in } \\
12 \text { months }(\mathrm{kg})\end{array}$ & $\begin{array}{l}\text { Cost/kg body } \\
\text { weight (Rs) }\end{array}$ & $\begin{array}{l}\text { Total cost } \\
\text { (Rs) }\end{array}$ & $\begin{array}{l}\text { Cost/kid } \\
\text { (Rs) }\end{array}$ & $\begin{array}{l}\text { Cost/kg body } \\
\text { weight (Rs) }\end{array}$ & \\
\hline Gr-3 (RSFTR) & 1126.54 & 33.17 & 33.96 & 1350.53 & 135.05 & 4.07 & 4079.00 \\
\hline Gr-2 (KFTR) & 1102.96 & 24.36 & 45.28 & 1379.73 & 137.97 & 5.66 & 3699.00 \\
\hline $\mathrm{Gr}-1$ (CFCR) & 1062.96 & 17.69 & 60.09 & 1173.62 & 117.36 & 6.63 & 43000.00 \\
\hline
\end{tabular}

rainy season. The kids under groupl suffered from environmental stress and body weight affected significantly $(P<0.01)$. But less stress was in groups 2 and 3 . Season, treatment and age significantly affect body weight of all 3 groups. Thus, their DMI and CPI were lower as compared to third group. The lowest growth rate was observed in first group, this was obviously due to maximum stress condition (concrete floor with concrete roof house) on the kids which lead to the lowest DMI and CPI all over the period. The highest values of daily average temperature $\left({ }^{\circ} \mathrm{C}\right)$ was under concrete roof shelter which varied from $13.55 \pm 0.60$ to per $\mathrm{kg}$ body weight of raised slotted floor with thatched roofed shelter was somewhat less as compared to concrete floor with concrete roof housing. Total fixed cost was quite less in both kuccha shelters as compared to concrete shelter for kids. The study concluded that the raised-slotted floor with thatched roof shed is the best suited for crossbred female kids in terms of growth, feed conversion efficiency and economics. The kuccha floor with thatched roof shed has good practical economic significance and also better for crossbred female kids as compared to the concrete floor with concrete roof shed. 


\section{REFERENCES}

Angami M, Baruah $\mathrm{K}$ K and Saikia B N. 1992. Growth response, feed efficiency and digestibility of nutrients in female crossbred goats fed different levels of energy. Indian Veterinary Journal $69(8): 707-10$.

Ghosh $N$ and fan $\$$. 1994. Comparative thermo-adaptability of Black Bengal goat and Sahabadi sheep. Indian Journal of Animal Sciences 64(2): 207-09.

ISI. 1978. Indian Standarts C'nde of Practice for Sheep and Goat Housing 152733. Indian Standards Institution, New belhi.

Jagadale P N. 1981. "Elfeet of different housing system on the performance of lactating Beetal goats'. M. Sc. Thesis, NDRI, Karnal, Haryana 132001.

Jnikishan K. Chhabra A and Arora S P. 1982. Growth rate and nutrients utilization by crossbred kids at two levels of feed intake. Indian. Iournal of Dairy Sciunces 35(2): 123-27.

Singh Khub, Puncet K. Sítini A L and Bhattacharyya N K. 1989. Influence of commonly used roofing material on microclimate in animal house in hot semi-arid zone. Indian Journal of Dairy
Sciences 42(3): 505-10.

Krishna $N$ and Prasad I A. 1985. Effect of stall-feeding on Jamunapari weaner kids on performance and carcass characteristics, Cheiron 14(4): 173-77.

Mishra K C and Ghel J C. 1990. Body weight at birth and growth rate in Sikkim local goats. Indian Journal of Animal Sciences 60(4): 490-91.

Nand K. Virk A S and Yadav I S. 1990. Relative utilization of nutrients by Bectal and Beetal Black Bengal goals. Intian Journal of Animal Sciences, 60(6): 743-45.

Rokde S N and Tomer OS. 2001. Eflect of housing systems and parabolic supplementation on methane production and body composition of crossbred calves. Indian Journal of Animal Sciences 71(5): 468-71.

Snedecor W G and Cochran G W. 1989. Statistical Methods. Oxford \& IBH Pub. Co., Pvt. Ltd, New Delhi, India.

Yadav S K and Singh C. 1995. Growth performance of female kids under different management systems. Indian. Jonrnal of Dary Sciences 48(2): 174-76. 